\title{
A név mint intertextuális nyelvi egység az Esti Kornél-novellákban
}

1. Bevezetés. Az alábbi tanulmányban a címszereplö nevének intertextuális szerepét és jellegét vizsgálom az Esti Kornél-novellákban. Az Esti Kornél címü kötet kritikai kiadásának keletkezéstörténeti fejezete jegyzi meg, hogy „Esti figurája egyike a magyar irodalom legtöbbet értelmezett, legtalányosabb hőseinek. Eredete bizonytalan és sokrétü, sokan, sokféleképpen próbálták megfejteni" (TóTH-CZIFRA 2011a: 519). Mindemellett és a számos elemzés, értelmezés ellenére tovább növeli a szövegek körüli, egyértelmúen meg nem válaszolható kérdések számát a müfajhoz köthető kéziratos anyag hiányán kívül (TóTH-CZIFRA 2010: 65, 2011b: 464-465) az Esti Kornél-kötetek szövegegyüttesei müfaji besorolásának, valamint múfaji meghatározhatatlanságának kérdése, „,mely mindmáig nyitott kérdés a magyar irodalomtudományban" (1. pl. SZEGEDY-MASZÁK 1980: 103-151; TÁTRAI 1997: 44; SZEGEDY-MASZÁK 2010a: 318-355; ARANY 2017: 422; TÁTRAI 2017: 209-301). A szövegek müfajmeghatározásaira tett kísérletek a novellaciklusszerü felfogástól a regényszerü értelmezésig terjednek (TÁTRAI 1997: 44). Jelen tanulmánynak nem az a célja, hogy a fent említett bizonytalanságokban állást foglaljon, hanem inkább az, hogy az Esti Kornél-nak mint az életmüben és két, a nevet címében viselö kötetben is visszatérö névnek az intertextuális jellegủ olvasást implikáló szerepét körüljárja.

2. A név inter(kon)textuális volta. A névadás paródiában betöltött szerepével kapcsolatban említi meg SLíz MARIANN, hogy a tulajdonnév többek között olyan tulajdonsággal is bír, hogy aktuális kontextusa, aktuális megvalósulása mellett képes felidézni korábbi környezeteit is (SLíz 2013: 83; vö. még PÁJI 2016a, 2016b; VÁCZINÉ 2018: 67), valamint a mentális lexikonunkban hozzájuk kapcsolódó fogalmakat. BENYOVSZKY KRISZTIÁNnak a név intertextuális jellegével kapcsolatos friss kutatása olyan müvekre irányult, amelyekben valamilyen szempontból Hercule Poirot-t megidéző, rá emlékeztető szereplőkkel találkozunk (BENYOVSZKY 2018). BENYOVSZKY hangsúlyozza azt a jelenséget - ami egyébként a Kosztolányi-életmü darabjait olvasva is igazolható -, hogy az általa vizsgált müvekben a teljes vagy részleges névegyezés az intertextuális olvasás felé nyit utat.

Ugyanezt tapasztalhatja az olvasó akkor is, ha egy adott életmủ eltérö szövegeiben tér vissza egy más szövegből már ismert név. Ilyen tulajdonnév a Kosztolányi-életmüben például a Sárszeg, az Anna vagy éppen a Kornél és az Esti Kornél név is (PÁJI 2016b: 85-86). Fontos megjegyezni - és az Esti Kornél múfaji bizonytalansága, múfaji többrétüsége kapcsán majd érdemes visszatérni - arra, hogy a név által korábbról felidézett kontextusok nemcsak egy irányba, az azonosságok kihangsúlyozódása felé hatnak, amikor a név aktuális olvasata során tudatosan vagy automatikusan felidézzük a név korábbi szöveghelyeit (SZEGEDY-MASZÁK 2010a; PÁJI 2016a: 86). A név általi, a különböző szövegek egymást felidéző jel- 
lege ugyanis árnyalhatja is az olvasónak a nevet viselő figurával vagy figurákkal kapcsolatos összképét, a név asszociációkból felépülő jelentésrétegeit, illetve ütköztethetik is azokat, amennyiben az aktuális megvalósulással kapcsolatban olvasottak ellentmondásban állnak a nevet viselőhöz köthető korábbi információkkal. BENYOvSZKY jegyzi meg Dumas Poe-t olvas vagy fordítva? Egy irodalmi esettanulmány névszemiotikai tanulságai címú írásában, hogy a név szemantikai tartalma a vonatkozó információk fokozatos adagolásával párhuzamosan egyre képzetgazdagabb lesz, ugyanis a név magába süríti mindazt, amit a szereplőről a szöveg mond (BENYOVSZKY 2014: 283). Ebben a felfogásban tehát a szereplő nem más, mint a rá vonatkozó szövegbeli információk összessége, melyet a név köt össze, eredője a mű szerzője, az újraalkotó pedig a befogadó (BENYOVSZKY 2014: 283). A témával kapcsolatban figyelemre méltó SLíz MARIANN-nak A nemlétező lovaggal kapcsolatos tanulmánya is. Ebben a Calvino-müben a mese fiktív történetének megfelelően végletesen fejeződik ki a fenti olvasói tapasztalat: a test nélküli lovagot csak a neve köti a létező világhoz, ,csak az akarata és hosszú, előkelőséget kifejező neve tartja össze" (SLíz 2007: 161-162).

Tovább árnyalja a képet, valamint az olvasó részéről az irodalmi figurához köthető lehetséges asszociációk sokaságát és azok lehetséges halmazát az a tény, hogy egy olyan név esetében, mint amilyen például az Esti Kornél Kosztolányi életmüvében, az olvasó nem feltétlenül ismeri a név valamennyi előfordulását és az azt tartalmazó összes szöveget, még csak az adott író szépirodalmi munkásságát tekintve sem, nem beszélve a nevet allúzióként az irodalomtörténet során később felhasználó szövegekröl. BENYOVSZKY veti fel a Poirot alakját idéző krimiirodalom kapcsán, hogy az azonos név önmagában még nem szavatolja két figura identikusságát, hiszen akár az írói stratégia része is lehet, hogy a néven kívül semmilyen más közös tulajdonságuk nincs a szereplöknek (BENYOVSZKY 2018: 280). Mint látni fogjuk, ennek a felvetésnek különösen fontos szerepe lesz az Esti Kornél-novellák esetében, illetve az Esti Kornél címet viselő 1933-as kötet belső ellentmondásait, illetve az Esti Kornél nevet viselö figura jellemzőit szembesítve különböző szövegekben. SZEGEDY-MASZÁK MIHÁLY elképzelése szerint - melyet a kritikai kiadás is idéz - az Esti Kornél-szövegek kötetekké alakításkor Kosztolányi „olyan címszereplöt formált, akinek lényéből hiányzik a jellem megkövetelte összetartozás, viszonylagos állandóság” (id. VERES 2011: 740), hozzátéve, hogy „a mü jelrendszerében a jellem nem számít érvényes egységnek". A fenti elgondolásokra vezethető vissza, hogy a kritikai kiadás szerint az Esti Kornél címet viselő müben az egyes, Esti Kornél figuráját érintő következetlenségek - amelyekre a későbbiekben fogok kitérni - tudatosak, célzatosak, a történet lényegéhez tartoznak (SZEGEDY-MASZÁK 2010a: 334; TÓTH-CZIFRA 2011a: 498, 513).

3. A tanulmány intertextualitás-felfogásáról dióhéjban. Megállapítható, hogy az intertextualitásnak nagyon gyakori módja egy alkotó saját szövegei közötti kapcsolat (SZIKSZAINÉ 1999: 339). Jelen tanulmány elfogadja és hasznosíthatónak véli SZIKSZAINÉ azon definícióját, amely az intertextualitást konkrét szövegek között asszociatív úton létrejövő kapcsolatként határozza meg (SzIKSZAINÉ 1999: 338). Ennek megfelelően egy adott életmüvön belül a különböző 
szövegekben visszatérő név ilyen, alapvető intertextuális jellegü nyelvi egységnek tekinthető. A fent leírtakhoz (ti. az 1933-as Esti Kornél-kötetben felmerülö következetlenségek magyarázatához) kapcsolható az a gondolat, hogy a másik szöveget magába fogadó szöveg, az intertextus a jelentéssürítéssel gazdagabbá válik, és ez mindig legalább kétféle olvasatot feltételez, mégpedig az aktuális értelem mellett a megidézett szöveggel harmonizáló vagy annak ellentmondó értelmüt (SZIKSZAINÉ 1999: 331).

Magát az intertextualitást mint jelenséget, valamint ezentúl a név által létrejövő inter(kon)textuális olvasatokat jelen tanulmány olyan jelenségként fogadja el, amely az irodalom történetiségének egyik legalapvetőbb eleme, s mely minden korszakban gyakori és ismert funkció volt (KULCSÁR-SZABÓ 1998: 497, 500), így az irodalmi hagyomány „létmódjának” alapvető jellemzője (KULCSÁR-SZABÓ 1998: 500). E tanulmány intertextualitás-fogalma leginkább a restriktív intertextualitás-felfogással rokonítható, amely elgondolás a radikálisan tág intertextualitás-értelmezést leszükíti a szövegek között megragadható konkrét utalásokra és kapcsolatokra (GYURICZA 2016: 73). A nyelvtudományi vizsgálatok számára GYURICZA (2016: 74) szerint leginkább ez a restriktív intertextualitás-koncepció bizonyult alkalmazhatónak.

4. Az Esti Kornél-figura a Kosztolányi-életmüben. A kritikai kiadás és ARANY ZSUZSANNA is felveti, hogy Kosztolányi az Édes Annával ellentétben soha nem adott magyarázatot Esti Kornél nevére, a név eredetére, valamint nyilatkozatot, levelet sem találunk az alakkal kapcsolatban (TóTH-CZIFRA 2011a: 524; ARANY 2017: 423), csupán kétszer nyilatkozott az Esti Kornél-szövegekröl a Színházi Élet címü folyóiratban a Csók- és a Vörös Ökör-történetek kapcsán.

Mind a kritikai kiadás, mind ARANY ZsUZSANNA felhívja a figyelmet, hogy a Kornél keresztnév már a húszas években foglalkoztathatta Kosztolányit, mert az Édes Annában Vizy Kornél néven szerepeltette Anna gazdáját (TóTH-CZIFRA 2011a: 524; ARANY 2017: 422). Kosztolányi Dezsőné regényes életrajza két ízben említi a Kornél nevet és próbál rá magyarázatot adni, de mindkét esetben reflektál magyarázatának bizonytalanságára is. Az első ilyen visszaemlékezést Kosztolányinak és fiának, Ádámnak a kapcsolatát felidézve teszi Kosztolányiné: „Van egy közös játszi alakjuk: hol Kornélka, hol Kálmánka, a rossz kisfiú, aki az ő második gyermeke, de olyan rossz, hogy a kéményben lakik és oroszlánpaprikást eszik. (Talán Esti Kornél kisgyermek korában)" (KosZTOLÁNYINÉ 2004: 230, kurziválás tölem P.G.). A második ilyen értelmezés egy hosszabb magyarázat, amelynek kiindulópontja éppen a név eredetére való rákérdezés: „Esti Kornél? Hogy hogyan támadt ez a név? Igazán magam sem tudnám megmondani. Talán a pesti polgár alakjából, aki nem derüs, világos, mint a nappal, de baljós és kétes, akár az este, keresztneve Kornél, tehát polgár, akár Vizy Kornél, Édes Anna Vizy Kornélja, de sokkal-sokkal bonyolultabb és veszélyes, furcsán ön- és közveszélyes, kissé az elmebaj határán, irracionális, mint maga az emberi élet. Tetszett neki ez a név, de sohasem elemezte keletkezését. Én is önkényesen teszem. Ez az alak, az ő érzelmes és polgári énjének csúfondáros és korlátlan mása, aki kimondja és fóképpen megteszi azt, amit ő szeretne" (KosZTOLÁNYINÉ 2004: 279, kurziválás tőlem P.G.). Névtani szempontból 
érdekes kérdést vethet fel, hogy miért érzi Kosztolányiné egyértelmüen polgárinak a nevet. Ennek oka lehet az olvasói asszociáció útján keletkező névhangulat, amely nem kizárólag szubjektív, hanem ahogyan HAJDÚ MIHÁLY fogalmaz, kialakulásának gyakran társadalmi, névhasználati oka van, attól függően, hogy mikor és kik körében válik gyakorivá az adott név, jellemző lesz arra a csoportra, az adott társadalmi rétegre fog utalni (HAJDÚ 2003: 115). Bár a Kornél név az adott korszakra (1921-1944) vonatkozóan és általában is ritka névnek mondható (vö. HAJDÚ 2003: 572-573, ahol nem szerepel az összesítésben sem), Kosztolányiné akár szokatlan, városias hangzása miatt érezhette polgári névnek. Másrészt, amint a magyarázatából kitünik, az írói életművön belüli korábbi névviselő, Vizy Kornél alakja is hatással volt rá a név keltette konnotációk értelmezésekor.

SZEGEDY-MASZÁK veti fel, hogy Esti Kornél alakját célszerü többféle eredetre visszavezetni (SZEGEDY-MASZÁK 2010a: 328). Szerinte az sem lehet kizárt, hogy a névválasztáshoz hozzájárult Bors Lászlónak az Újvidéki Színház címü folyóiratban 1917-ben, folytatásokban megjelent, Vidéki riporter címú kisregénye, melynek föszereplője Pesti Kornél (SzEGEDY-MASZÁK 2010a: 324). Megemlíti azt a szerző kapcsán közismert tényt is, hogy Kosztolányi gyüjtötte a neveket és fel is használhatta azokat müveihez, így feltételezése szerint akár az Ujság címü folyóiratnak azt az 1908-as számát is láthatta, olvashatta, amelynek a címlapján Öszi Kornél névvel szerepel egy írás (SZEGEDY-MASZÁK 2010a: 324).

Érdemes röviden szólni az Esti Kornél név fordításokban alkalmazott megoldásairól. Példaképpen a BENYOVSZKY KRISZTIÁN vonatkozó tanulmányában (2010: 13-30) elemzett, a cseh és a szlovák fordítók által alkalmazott megoldásokat idézem fel. A szlovák fordítás címében Karol Wlachovský elhagyta Esti Kornél nevét,'Esti románcok' címet adva a münek, érthetővé téve ezáltal a szlovák olvasó számára a családnév közszói jelentését (BENYOVSZKY 2010: 29), s utat nyitva a konnotációknak. Érdekes ugyanakkor, hogy a 'románcok' szó szerepeltetésével a címben müfaji utalást is tesz. Ezzel szemben a cseh fordító, Anna Rossová lefordította a címszereplő családnevét: Kornel Večerek. BENYOVSZKY szerint az -ek kicsinyítő képző Esti gyermeki vonásaira utal, és megidézi például az első fejezetet: „Gyermekkorunkban te voltál a felnőtt, te vezettél, te nyitottad ki a szemem. Most te vagy a gyermek" (Kosztolányi 2011: 24). A név előhívhatja az olvasóban a večirek szót is, ami 'estély'-t jelent, és a nagyvilági társasági élet miliojjét is megidézheti (BENYOVSZKY 2010: 30).

Mindezek kapcsán érdemes megemlíteni a családnév közszói konnotációit is, amelyek - a fordítói szándékokat, magyarázatokat és Kosztolányi névadással kapcsolatos tudatosságát figyelembe véve - a magyar nyelvü eredeti esetében sem lehetnek csupán véletlen választás eredményei. Inkább sejthető, hogy az író tudatosan operált a családnévül alkalmazott név közszói jelentésének gazdag szerkezetével, csakúgy, mint Édes Anna családnevének kiválasztásakor. A névhez kapcsolódó asszociációkról, valamint az ehhez köthető írói-olvasói tudatosságról szólva érdemes utalni azon - a jelen tanulmány későbbi részében hivatkozott - névasszociációs kérdőívvel végzett kutatásra, amely kimondottan a Kosztolányi-életmüben felbukkanó neveket vizsgálta (PÁJI megj. e.). E vizsgálat kapcsán dióhéjban megállapítható, hogy a név közszói jelentésének, jelentéshangulatának 
tudatos vagy kevésbé tudatos módon, de kiemelt szerepe lehet a nevet viselő szereplőkhöz kapcsolódó olvasói asszociációkban, és így a szereplőkről az olvasóban kialakuló kép megalkotásában. E jelenség ismeretében a szerző is tudatosan élhet ezzel az eszközzel az írói névadás, névválasztás során. (Hasonló vizsgálatot végzett és hasonló eredményre jutott korábban SLÍZ MARIANN Lázár Ervin írói névadásának vizsgálata kapcsán; kutatása mintául szolgált a névasszociációs kérdőívem felépítéséhez és a vizsgálat elvégzéséhez is; SLíz 2014: 217-226.)

5. Az Esti Kornél-szövegcsoportok. Az Esti Kornél-szövegek együttes vizsgálatánál nem hagyható figyelmen kívül az a tény, hogy ezeknek az írásoknak az elsődleges színtere a folyóiratok, napi- és hetilapok első-, másod- és sokadközlése (TÓTH-CZIFRA 2011b: 465). Az első szöveg, amely Esti Kornél „színrelépéséhez" köthető a sajtóban, az a Nyugat 1925. november elsejei számában megjelent Ujságíró címü szöveg, mely az Esti Kornél címü kötet (1933) későbbi nyolcadik fejezete, Mogyoróssy Pali megörülésének története. Ebben a szövegben még a Kornél keresztnév nélkül szerepel Esti (TÓTH-CZIFRA 2010:68; 2011b: 480), csak családnévvel említve. Az Esti Kornél-szövegcsoportokról szólva meg kell különböztetni a kötetformában 1933-ban megjelent Esti Kornél címü kötetet, melybe tizennyolc szöveget válogatott be Kosztolányi, valamint az 1936-os megjelenésű Tengerszem címü kötetet, amelynek Esti Kornél kalandjai címet viselő ciklusa tizenhét novellát tartalmaz. Ezenkívül a szakirodalom számol még azokkal az Esti Kornél-novellákkal is, amelyeket Kosztolányi kötetbe nem vett fel (TÓTH-CZIFRA 2010: 64).

A szövegek kapcsán érdemes azt is megjegyezni, hogy a többszöri folyóiratközlések miatt számos szövegváltozattal számolhatunk (TÓTH-CzIFRA 2010: 68), valamint érdekes tény, hogy egyes szövegek kifejezetten Esti Kornél-szövegekként láttak napvilágot, míg másokat utóbb, a kötetté formáláskor alakított át a szerző Esti Kornél-novellává (TÓTH-CZIFRA 2010: 68), tehát ezekben a történetekben eredetileg nem szerepelt Esti Kornél neve. LENGYEL ANDRÁs szerint egyébként a Kornél keresztnév megjelenése azért beszédes a szövegekben, mert a keresztnévvel való szerepeltetés már egy összetettebb figura megképződését mutatja az életmüben (LENGYEL 2000: 223). A Kornél nevet is tartalmazó első szöveg az Esti Kornél naplója címen 1929-ben, a Pesti Hírlapban jelent meg, mely a későbbi Csók címü novella, az 1933-as kötet későbbi harmadik fejezete. További, a neveket érintó érdekesség, hogy ebben a szövegben is élt Kosztolányi a Pacsirta és az Aranysárkány kéziratos és gépiratos változataiban is jól megfigyelhető névváltoztatás jelenségével: a fennmaradt kézirat-változatban az Estit megcsókoló lány neve még nem Editke, hanem Lujzika (TóTH-CZIFRA 2011a: 502). A Lujzi név az Aranysárkány kéziratában is felbukkan, méghozzá Novák Antal unokahúgának, a végleges változatban Pepike nevet viselö figurának a névváltozatai között (PÁJI megj. e.; 1. még a témával kapcsolatban PÁJI 2016b, valamint PARÁDI 2014: 1037-1038).

Bár a Lujzika/Lujzi névváltozatokon utólag módosított a szerző, a névváltozatok kapcsán érdemes megjegyezni Kosztolányinak azt a neveket is igen gyakran érintő eljárását, hogy egy-egy ötletet, motívumot többször, újra és újra körüljárt, attól függetlenül, hogy feltétlenül kapcsolatot akart volna teremteni a két, azonos motívumot, nevet tartalmazó szöveg között (TóTH-CZIFRA 2011a: 502). Ilyennek 
tekinthetők az életműben a már említett Sárszeg, Anna, Kornél nevek (vö. PÁJI 2016a), de egyéb olyan, egy-egy történet vagy a teljes életmủ szempontjából kisebb „hatókörü”, kevésbé kiterjedt jelentésszerkezettel rendelkező és a befogadó részéről kevésbé kiterjedt asszociációs hálózatot mozgósító nevek is, mint például a Kalmár és Társa A rossz orvosban, valamint a Weisz és Társa a Pacsirtában. Mindkét szöveg a „Társ” ismeretlenségét, nevének hiányát veti fel egy gondolat erejéig (Kosztolányi 2013: 193-195, 2015: 148). A fenti példák jól illusztrálják, hogy a név interkontextuális volta révén akár könnyen és többé-kevésbé önkéntelenül, asszociatív úton is felidézheti az olvasóban korábbi környezeteit. (A későbbiekben a már említett kérdőíves vizsgálat kapcsán térek majd ki erre részletesebben is.)

6. Müfaji kérdések és bizonytalanságok. SZEGEDY-MASZÁK MiHÁLY veti fel a kérdést, hogy az Esti Kornél-novellákat vajon elégséges-e az alapján elkülöníteni a szerző más műveitől, hogy szerepel benne Esti Kornél neve (SZEGEDYMASZÁK 2010a: 321). SZEGEDY-MASZÁK elgondolása szerint az Esti Kornél és az Esti Kornél kalandjai olvashatók egységként, azonban a mü folytonossága nem nyilvánvaló, minduntalan megcáfolódik (SZEGEDY-MASZÁK 2010a: 334). SZEGEDY-MASZÁK (2010a: 334) szerint célszerü az Esti Kornél-szövegekröl úgy gondolkodnunk, mint egy elképzelt mü töredékeiről. Az Esti Kornél nevet viselő figuráról, szokásairól, sajátosságairól a különböző szövegekben egyrészt az elsődleges elbeszélőtől, másrészt a másodlagos elbeszélőtől, magától Esti Kornéltól kapunk információkat, ezáltal kétértelmüvé, viszonylagossá, lebegtetetté válnak ezek a jellemzők egymást értelmezve. Rögtön az első fejezet, mely kimondottan az Esti Kornél kötet nyitófejezetének készült, elbizonytalanítja a szövegek müfaji kérdését, illetve rámutat arra, hogy mely müfajokat függeszt fel a kötet. Ilyen müfajok a regény és az önéletrajz SZEGEDY-MASZÁK értelmezésében. TÁTRAI viszont az 1933-as kötetet, az Esti Kornélt az egyes fejezetek előtt álló paratextusok miatt egységes, önálló szövegként fogja fel, és ezért a regényszerü értelmezés mellett foglal állást (TÁTRAI 2000: 50, 2017: 296), bár hangsúlyozza, hogy a szöveg nem kíván prototipikus regény lenni, hanem más müfajok jellemzőivel keveredik (TÁTRAI 2017: 296). Emellett ö is elismeri, hogy az összefüggő szövegként való befogadás ellen hat, hogy a „történet szintjén nem beszélhetünk kauzálisan és temporálisan összefüggő cselekményszerkezetről" (TÁTRAI 2000: 44). SZEGEDYMASZÁK a múfaji kérdés mellett kiemeli azt a módszerét is a szerzőnek, hogy a kihagyást, a hiányt helyezte a történet középpontjába (SZEGEDY-MASZÁK 1980: 110-112). Kosztolányi módszere a szövegrészek, az egyes fejezetek közötti viszony tekintetében az, hogy „egyetlen későbbi fejezetben sem dolgoz ki újabb adalékokkal korábban már elbeszélt történetet" (SZEGEDY-MASZÁK 1980: 110112). Ennek fényében különösen fontos szerepe van a tulajdonnévhez köthető jellemzőknek, befogadói asszociációknak. HIMA GABRIELLA elgondolása szerint az Esti Kornélban ,a mü egységét szüzsé hiányában is” az alak teremti meg (HIMA 1992: 164-165). Ez azért fontos, a mủ névhasználatát érintő és az intertextuális olvasást támogató megállapítás, mert a HIMA által említett egység nyelvi tekintetben éppen a főhős nevének szövegbeli jelenléte által valósulhat meg. 
Nagyon fontos, a nevet, illetve a név mögött meghúzódó figura vagy figurák önazonosságára vonatkozó kérdést vet fel SZEGEDY-MASZÁK, szerinte ugyanis Esti Kornél nem regényhős (SzEGEDY-MASZÁK 2010a: 347), hiányzik az alakjából az összetartó egység, az egységet alkotó megkülönböztető jegyek az egyes szövegeket egymás után olvasva pedig nem állnak össze koherens egésszé. Maga az első fejezet, amelyet kimondottan a kötet összeállításakor írt Kosztolányi, a fenti megállapítást erősítve mutatja be az olvasó számára Estit: „Esti Kornél tényleg volt, de nem volt jogi személy” (Kosztolányi 2011: 20). Ez az első fejezet a kötetfejezethez viszonyítva a többi szöveggel ellentétben később jelent meg folyóiratban (a Pesti Hírlap hasábjain Esti Kornél leleplezése címmel; TóTH-CZIFRA 2011b: 469), és erőteljesen érezhető benne az a szerzői törekvés, hogy előképet és magyarázatot nyújtson Esti Kornél alakjáról és az elbeszélői viszonyokról a további fejezetekkel kapcsolatban. Az első fejezet abból a szempontból is kivételesnek tekinthető, hogy a második és a harmadik fejezetek mellett talán ebben a fejezetben kapcsolja a legtöbb „leíró” jellegü tulajdonságot az elbeszélő Estihez: „Untam ódivatú, magas-nyitott gallérjait, vékony-sárga nyakkendőit és vastagzöld szójátékait is. Fárasztott az eredetieskedése” (Kosztolányi 2011: 9).

Az azonos név ezekben a szövegekben az inter(kon)textuális befogadást erősíti, ugyanis a tulajdonnév azonos alakja egy korábbi és egy új szöveg viszonyában megidézi az olvasóban és a névhez „tapasztja” a név korábbi szövegkörnyezetét, az azonos név útján a szereplőhöz köthető jellemzőket. Ez az intertextuális eljárás kibővítheti, árnyalhatja a névhez kapcsoló addigi információkat az olvasó mentális lexikonában, de akár cáfolhat is korábbi, a figurához köthető ismereteket.

\section{7. „Az ő számára a nyelv az a szemüveg, amellyel látni képes.” Hason-} lóságok és következetlenségek az Esti Kornél név köré szőtt tulajdonságegyüttesben. BÁRDOS is hangsúlyozza azt a névviselést, a név általi intertextuális olvasásmódot is illető megállapítást, hogy a szövegek ,,sorozatából nem képződik semmiféle koherens, egységes tulajdonságokat hordozó karakter" (BÁRDOS 1995: 271-275), valamint hogy az Esti Kornél ,világképe [...] az állítások kétértelmüségére, az ellentéteknek [...] egyidejü igazságára épül” (BÁRDOS 1995: 271-275). Mint látni fogjuk, éppen ez a viszonylagosság az egyik olyan tényező, ami Esti Kornél egyik többé-kevésbé jellemző tulajdonságaként említhető fel. A szakirodalom is megállapítja, hogy Esti Kornél alakja az 1933-as keletkezésü kötetet olvasva ellentmondásokat hordoz magában, melyek azonban szándékosan, célzatosan maradhattak a kötetben a szerző részéröl. Az egyik ilyen ellentmondásként említhető az elbeszélő és Esti barátságának kezdete (SZEGEDY-MASZÁK 2010a: 334). Az első fejezetben az elsődleges elbeszélőtől a következőket tudjuk meg: „Emlékezetem nem oly régi, mint barátságunk. Ennek kezdete még csecsemőkorom ősemberi homályába vész el" (Kosztolányi 2011: 11). A hatodik fejezetben viszont, „melyben szert tesz óriási örökségére” Esti, az elbeszélővel társalogva megjegyzi, hogy: „Még nem ismertelek téged” (Kosztolányi 2011: 132). A hatodik fejezet története szerint ekkor harmincéves a föszereplö. Érdekes és a mü töredékességével, valamint a szöveget átható viszonylagosság gondolatával jól harmonizál, hogy az első információt a szöveg szerint az elsődleges elbeszélőtől 
kapjuk, míg a második információ Estihez, a másodlagos elbeszélőhöz köthető. Ez a kettősség, értékviszonylagosság az első fejezetben azáltal is hangsúlyossá válik, hogy az első, bevezető fejezet szerint ketten jegyzik a kötetet: „Közösen írjuk. [...] Te tedd rá a neved. Viszont az én nevem legyen a címe. [...] Egy esztendeig havonta összejöttünk egyszer-kétszer és ő mindig hozott valami úti élményt, vagy regényfejezetet az életéből. [...] Történeteit részint gyorsírási jegyzeteim alapján, részint emlékezetből papírra vetettem s utasítása szerint rendeztem. Így jött létre ez a könyv" (Kosztolányi 2011: 29).

A másik következetlenség szintén ehhez a hatodik fejezethez köthető: eszerint ugyanis Estinek nincs testvére, rokonai sincsenek egy gazdag gyároson kívül (Kosztolányi 2011:132), míg az ötödik fejezet végén arról értesülünk, hogy ,jó fiú is volt és szerető testvér" (Kosztolányi 2011: 126).

Azonkívül, hogy Esti Kornél neve intertextuális olvasásmódot indukál az egyes fejezetek között, érdekes az a kötetrendező eljárása is Kosztolányinak, hogy a cselekmény és a figura folytonosságának és következetességének hiánya ellenére Esti Kornél nevén kívül más nevekkel is igyekezett laza intertextuális olvashatóságot létrehozni egyes fejezetek, sőt, az 1933-as Esti Kornél kötet és az 1936-os Esti Kornél kalandjai ciklusok között is. Ez az eljárás a szóban forgó fejezeteket illetően utólagosnak mondható. Patakinak és Ürögi Daninak külön „,fejezete” van (tizenötödik és tizenhetedik fejezetek) az Esti Kornélban, de utólag az ötödik fejezet népes kávéházi törzsközönsége közé is bekerült a nevük, holott a fejezet folyóirat-változataiban még nem szerepeltek (TóTH-CZIFRA 2011a: 512). Pataki a Sakálok címü szövegben is felbukkan, illetve a Tanú címü szövegben is. Az Esti megtudja a halálhírt címü novellában Winter Sándor a Szíriusz kávéházból telefonál Estinek, és a kávéház neve szintén támogathatja az intertextuális olvasást, megidézheti az ötödik fejezet kávéházi epizódját. Ugyanilyen szerepü tulajdonnévnek tekinthető az ötödik fejezet és az Esti Kornél kalandjai ciklus Sárkány címủ novellájának viszonylatában a Független Magyarország folyóiratcím. A Sárszeg nemcsak az életmü tágabb kontextusában, hanem az Esti Kornél-novellákban is felbukkanó helynév. A harmadik fejezetben arról értesülünk, hogy Esti „Sárszegen nőtt fel, könyvek és orvosságos-üvegek között" (Kosztolányi 2011:42). Emellett az Esti Kornél kalandjaiban, Cseregdi Bandi történetében is Sárszegre utazik haza a címszereplő első jogi vizsgájának letétele után. Az ötödik fejezet kávéházi törzsközönségét illetően névtani szempontból is érdekes a kritikai kiadás „Tárgyi magyarázatok” címü fejezete (BíRÓ-BALOGH 2011: 555-566), melyben a fejezet szereplőinek feltételezhetó alakmásait illetően kap eligazítást az olvasó. Például Vándory V. Valért Tersánszky Józsi Jenővel, Gách Józsefet Csáth Gézával, Arácsyt, a festőt Gulácsy Lajossal azonosítja a kritikai kiadás. Érdekes lehet annak megfigyelése is a szövegben, és Esti Kornél alakjának egyik esszenciájaként határozható meg, hogy a kávéházi epizódban csupán egy nem különösebben meghatározott, nem markánsan megrajzolt egyede az asztaltársaságnak, inkább csak egy, az egyik tipikus figura a többiek mellett.

Az Esti Kornél alakját érintő következetlenségeken kívül érdemes szólni olyan tulajdonságairól is, amelyek akár változatokban ugyan, de visszatérő elemek a figura kapcsán. Az egyik ilyen fontos, a tulajdonnévvel gyakran együtt járó jellemzője a novellák Esti-alakjának az írói-költői mesterséggel, a nyelvvel való 
foglalkozással kapcsolatos. Ez a jellemző olyan, viszonylag állandó motívumnak tekinthető a történetekben, amely a lineáris cselekmény hiánya ellenére többékevésbé az Esti Kornélhoz kötődő olvasói asszociációk egyik gyakori és stabil összetevője. Erre a jellemzőre számos példa idézhető a szövegekből, amelyek a név intertextuális volta révén egymást erősítik. Az elbeszélő is egyértelmüen az íráshoz, az irodalomhoz köti Estit: „Bevallom, azelőtt sokszor csak afféle kákabélü, nemzetközi világjárónak tartottam, afféle félnótás irodalmi csodabogárnak" (Kosztolányi 2011: 186, kurziválás tőlem P.G.). A nyelvvel való foglalkozás, mint az alábbi példákból is látható, elsőrendü, szövegeken átívelő tulajdonságként jelenik meg ezekben a novellákban. „A nyelv létezési módjának fürkészése” SZEGEDY-MASZÁK szerint is olyan elemnek tekinthető a vizsgált novellákban, ami egységet adhat a lazán egymáshoz füzött történeteknek (SZEGEDY-MASZÁK 2010a: 351). Esti hol költőként, hol íróként, hol nyelvészként tủnik fel, illetve pozicionálja magát: „A kocsis üvöltözni kezdett, tetves fickónak nevezett, még az ostorával is felém suhintott, de én csak ámuldoztam, hogy mily remekül használja a rendhagyó igéket, mily mesterien egyezteti az alanyt az állítmánnyal, mily gazdag és változatos a szókincse $\mathrm{s}$ irónomat keresgéltem, hogy mindezt följegyzem. [...] Azt hihette, hogy valami vallásalapító vagyok, vagy örült. Pedig csak nyelvész voltam" (Kosztolányi 2011: 226-227, kurziválás tőlem P.G.). A hetedik fejezetben, a keleti villámvonaton Kücsüknek, a török lánynak tett vallomásában Esti a következőképp határozza meg magát: „Költő vagyok, a szavak szerelmese, bolondja (Kosztolányi 2011: 144), míg a harmadik fejezet vonatútja során így gondolkodik magáról: „Én írónak készülök [...] Olyan író akarok lenni, aki a lét kapuin dörömböl s a lehetetlent kísérli meg" (Kosztolányi 2011: 81).

A másik olyan jellemző, amely a tulajdonnév összetett jelentésszerkezete (típus és megvalósulás; 1. TolCSVAI NAGY 2008: 31, 38-39) által az Esti Kornél névhez köthetô intertextuális olvasat révén az alakhoz füződik és visszatérö jellemzőnek mondható ezekben a szövegekben, a már említett viszonylagosság gondolata. A harmadik fejezet végén Esti Olaszországba érve az alábbi módon jellemzi magát gondolatban: „Mindenki vagyok és senki. Vándormadár, átváltozó mủvész, büvész, angolna, amelyik folyton kisiklik az újjak [!] közül. Megfoghatatlan és átfoghatatlan" (Kosztolányi 2011: 87). A kilencedik fejezet bevezető gondolataiban, melyben a bolgár kalauzzal való „nyelv nélküli” társalgás történetét meséli el Esti, a következö kijelentést teszi, amely szintén jól illusztrálja azt, hogy a lazán kapcsolódó szövegekből kirajzolódó figura egyik alapértéke a kétértelmüség, ellentmondásosság, viszonylagosság belátása: „Miután mindezt kifejtettem, eszembe jutott, hogy ennek az ellenkezője is épannyira [!] áll, mint minden dolognak a világon" (Kosztolányi 2011: 174). Múfaji tekintetben érdemes megjegyezni, hogy ez a viszonylagosság, kettősség nemcsak az Esti-novellákban bukkan fel, hanem olyan lírai szövegekben is megidézi a név és a kettősség által Esti alakját, mint az Esti Kornél éneke és az Esti Kornél rímei (Kosztolányi 1943a, 1943b). Utóbbiban külön érdekes lehet a városnevek mentén felépített versszöveg (például: „Györ, / Kelet s nyugat közt állj hazámba, kedves / ör. [...] Gyerekkorom, mindig téged kereslek, / ha járom a poros-boros Szabadkát. [...] Ha nem leszek, mondd, elfeledsz-e, /Velence?"). Az Esti Kornél naplója címü 
publicisztikai írás, mely a Pesti Hírlapban jelent meg 1931. június 7-én, az Esti Kornél első fejezetére emlékeztetheti az olvasót, és Esti alakjának esszenciáját adja, gazdagítva az olvasónak a figurával kapcsolatos ,ismereteit”, benyomásait: „Ha ez a bérenc költő csak az előkelőket, gazdagokat, erőseket becsüli, azért, mert azok, te csak a névteleneket, ínségeseket, gyöngéket becsülöd, azért, mert azok. Ha számára föltétlenül ajánlólevél, hogy valakinek van családfája, a te számodra is föltétlenül az, hogy valakinek nincs családfája” (Kosztolányi 2002: 370).

8. Esti a kortárs szépirodalomban. A kritikai kiadás befogadástörténeti fejezete is felhívja a figyelmet rá, hogy az Esti Kornél-szövegeknek számottevő a szépirodalmi hatása (VERES 2011: 574-575). A közelmúltból figyelemreméltó ebben a tekintetben Esterházy Péter Esti címú müve (ESTERHÁZY 2010), mely a „kölcsönzött” név és alak által hangsúlyosan az intertextuális olvasatra játszik rá, de a szöveg és a név által megképződő figura nagymértékü töredezettségével, töredékességével kétségbe is vonja ennek lehetőségét. SZEGEDY-MASZÁK megjegyzi, hogy míg a címszereplö önazonossága már Kosztolányinál sem volt egyértelmü, addig Esterházy ennél messzebbre megy, nála a személyiség az azonosíthatatlanságig széttöredezett (SZEGEDY-MASZÁK 2010b), és ezzel csakúgy, mint a Kosztolányi-szövegek szerzője, hangsúlyosan felhívja az olvasó figyelmét a szövegben megkonstruált világok fikcionáltságára. Névtani szempontból és az intertextuális olvasat tekintetében fontos, hogy a szövegek közötti asszociációs kapcsolat elsősorban a tulajdonnév útján valósulhat meg a Kosztolányi-életmüből vett idézetek, utalások és a nyelvvel való foglalkozás, egyúttal annak széttöredezettsége mint hangsúlyos téma révén. Természetesen kisebb terjedelmü szövegek is szerepeltetik Esti Kornélt, érdekes intertextuális utalásrendszer létrehozva a név által. A már említett, jellegzetes Esti-tulajdonságok megjelennek ezekben a szövegekben is, és összekapcsolódnak a Kosztolányi-novellákkal, illetve a többi kortárs szöveggel is. Halmai Tamásnál például „magányára kényes literátor”-ként jelenik meg, és a már említett viszonylagosság, kettősség is felbukkan a figura kapcsán: "Mulattatta, hogy mindössze ennyi kell a legtöbbször, a mindenhez, a semmihez" (Halmai 2006a: 27). Természetesen az írás mint tevékenység is jól beazonosítható diagnosztikai tulajdonsága (BENYOVSZKY 2014: 253) a kortárs müben felbukkanó Esti-alaknak: ,írt, mint aki túl van az egészen és túl a részleteken (Halmai 2006b: 27). Érdekes Vathy Zsuzsa Bolgár kalauzom címü szövege is, mely a mottóul választott szöveggel paratextuális utalás révén teremt intertextuális környezetet az olvasó elé tárt szövegnek azzal, hogy az Esti Kornél kilencedik fejezetének bevezető mondatát idézi, mely természetesen tartalmazza a föhős nevét: „Ezt el kell mesélnem nektek, szólt Esti Kornél” (Vathy 2006: 47-51).

9. A névasszociációs kérdőív. Az Esti Kornél név kapcsán érdemes itt megemlíteni, hogy 2015-ben kérdőíves kutatást végeztem első- és másodéves magyar szakos hallgatók körében az ELTE BTK-n, mellyel a névhez kötődő olvasói asszociációkban felfedezhető tendenciaszerüségekre voltam kíváncsi, illetve ezeket az aszszociációkat igyekeztem mérhetővé tenni. Ez a vizsgálat mintegy előtanulmányként szolgált a későbbi, írói névadási stratégiákkal kapcsolatos kutatásomhoz is (l. PÁJI 
2016b). Az adatközlőként megkérdezett hallgatók nem kaptak arra vonatkozóan információt, hogy a feleletválasztós és a névhez köthető szubjektív asszociációkat vizsgáló kifejtett választ igénylő kérdésekben kapott nevek Kosztolányi-szövegekből származnak, és válaszukban ritkán is egyértelmúsítették, hogy a név hallatán egyértelműen egy Kosztolányi-szövegre asszociálnának. Ennek ellenére a kapott válaszok arra utaltak, hogy egyéni, a névhez köthető asszociációikra mégis hatással lehettek szépirodalmi olvasmányaik, valamint kimondottan fontos szerepe van a név közszói jelentéséhez kapcsolódó olvasói asszociációknak a kapott válaszokban, illetve az olvasónak a szereplőkre vonatkozó elképzeléseiben a név alapján.

A kifejtős választ igénylő feladatban arra kellett válaszolniuk az adatközlőknek, hogy milyennek találják az adott neveket, milyennek képzelik el viselőjüket, és milyen hangulatot ébreszt bennük a név. Hogy a nevekből ne derüljön ki egyértelmủen, hogy Kosztolányi szereplőinek neveiről van szó, a Kornél nevet például a Vizy és az Esti családnevek nélkül szerepeltettem, mégis kaptam olyan válaszokat, amelyekben a felsorolt jellemzők a két fiktív figurát idézik meg, bár a válaszadók az esetek nagy többségében ezt nem tették reflektálttá. Egy hallgató adta csak azt a reflektált választ, hogy a Kornél név számára Esti Kornélt idézi: „magyarosként rögtön Esti Kornélra asszociálok, az ő jellemétől nehéz elvonatkoztatni”. Voltak olyan hallgatók, akik inkább Vizy Kornélt, illetve egy hozzá hasonló karaktert idéztek meg válaszaikban, nem nevesítve: „komolynak tünő, befolyásos”; „távolságtartó, tekintélyt parancsoló, határozott, szigorú”. Más adatközlők viszont, válaszaik alapján, a nevet olvasva akár önkéntelenül is Esti Kornélra, illetve egy hozzá hasonló figurára asszociálhattak: ,az életet bölcsen megfigyeli”; , egy kicsit ficsúr, értelmiségi fiatal férfi”; „nem igazán találja helyét a világban [...] olykor nagyon boldog, máskor szomorú”; „rejtélyes költő”; „művészlélek”.

A fenti néhány példát idézve is látható, hogy Kosztolányi más szereplöihez hasonlóan tudatosan olyan nevet választott főhősének mind a családnév, mind az utónév tekintetében, amely gazdag jelentéshálózattal bír, és ezek az asszociációk a diagnosztikai tulajdonságoktól a teljesen szubjektív konnotációkig minduntalan visszaköszönhetnek a név különböző felbukkanásai alkalmával, annak intertextuális funkciója révén.

10. Összegzés. A fenti tanulmány az Esti Kornél-szövegegyüttesekben a címszereplő tulajdonneve által megvalósuló intertextuális olvasási lehetőséggel foglalkozott, mely a szöveg és a befogadó viszonyában reflektált vagy öntudatlan aszszociációkkal írható le. Ezek a szövegegyüttesek az életmüben - azonkívül, hogy vitatható müfajúak és egymáshoz lazán, leginkább a tulajdonnevek és egy-egy viszszatérö téma, illetve a történet linearitása, kifejtettsége által kapcsolódnak - hangsúlyozzák az elbeszélés fikcionális voltát. Az Esti Kornél név ezek között a szövegek között, sőt, a nevet szerepeltető kortárs szépirodalmi szövegekben is egyfajta asszociációs kapocsként müködik, intertextuális szereppel bír azáltal, hogy megidézi a tulajdonnév korábbi szövegkörnyezeteit és a névhez a korábbi szövegekben kapcsolt jellemzőket. A tanulmány egy olyan szempontra kívánta felhívni a figyelmet névtani megközelítése alapján, amely más szerzők és más típusú szövegek vizsgálata esetén is eredményesnek bizonyulhat. 


\section{Hivatkozott irodalom}

Arany ZsuzSAnNa 2017. Kosztolányi Dezső élete. Osiris, Budapest. 422-429.

BÁrdos LÁszló 1995. Utószó. In: Kosztolányi Dezső, Esti Kornél. Esti Kornél kalandjai. Unikornis, Budapest. 271-275.

BENYOVSZKY KRISZTIÁN 2010. Konnotáció és fordítás. In: JENEY ÉvA szerk., Szó és betü szerint a világ. Pont fordítva 10. Balassi Kiadó, Budapest. 13-30.

BENYOVSZKY KRISZTIÁN 2014. Dumas Poe-t olvas vagy fordítva? Egy irodalmi esettanulmány tanulságai. In: BAUKO JÁNOS - BENYOVSZKY KRISZTIÁN szerk., A nevek szemiotikája. Nyitrai Konstantin Filozófus Egyetem Közép-európai Tanulmányok Kara - Magyar Szemiotikai Társaság, Nyitra-Budapest. 246-266.

BENYOVSZKY KRISZTIÁN 2018. Névtorzítás és alakpárhuzam a krimiirodalomban. Magyar Nyelv 114: 278-287. https://doi.org/10.18349/MagyarNyelv.2018.3.278

BíRÓ-BALOGH TAMÁs 2011. Tárgyi magyarázatok. In: Kosztolányi 2011: Esti Kornél. Kritikai kiadás. Szerk. TÓTH-CzIFrA JúliA - VERES ANDRÁs. Kalligram, Pozsony. 555-566.

ESTERHÁZY PÉTER 2010. Esti. Magvető, Budapest.

GYURICZA KATALIN 2016. Az intertextualitás vizsgálata nyelvészeti szempontból. Magyar Nyelvör 140: 71-95.

Hajdú Mihály 2003. Általános és magyar névtan. Személynevek. Osiris, Budapest.

HALMAI TAMÁs 2006a. Esti Kornél karácsonya. Új Forrás 38/9: 26-27.

Halmai TAMÁs 2006b. Esti Kornél új esztendeje. Új Forrás 38/9: 27-28.

HimA GABRIELla 1992. Kosztolányi és az egzisztenciális regény: Kosztolányi regényeinek poétikai vizsgálata. Akadémiai Kiadó, Budapest.

Kosztolányi Dezső 1943a. Esti Kornél éneke. In: Kosztolányi Dezső összegyüjtött versei.

Révai, Budapest. http://mek.oszk.hu/00700/00753/html/vers1302.htm\#19 (2018. 07. 18.)

Kosztolányi Dezső 1943b. Esti Kornél rímei. In: Kosztolányi Dezső összegyüjtött versei. Révai, Budapest. http://mek.oszk.hu/00700/00753/html/vers1503.htm\#83 (2018. 07. 18.)

Kosztolányi Dezső 2002. Esti Kornél naplója. In: Kosztolányi Dezső, Nyelv és lélek. Sajtó alá rendezte RÉz PÁL. Osiris Klasszikusok. Osiris, Budapest. 370.

Kosztolányi Dezső 2011. Esti Kornél. Kritikai kiadás. Szerk. TóTH-CzIFRA JúLIA - VERES ANDRÁs. Kalligram, Pozsony.

Kosztolányi Dezső 2013. Pacsirta. Kritikai kiadás. Szerk. BuCsics KATALIN. Kalligram, Pozsony.

Kosztolányi Dezső 2015. Béla, a buta. A rossz orvos. Kritikai kiadás. Szerk. BARTóK ISTVÁN - SÁRKÖZI ÉVA. Kalligram, Pozsony.

Kosztolányi DezSŐnÉ 2004. Kosztolányi Dezső. Aspy Stúdió Kiadó, Budapest.

KULCSÁR SZABÓ ZOLTÁN 1998. Intertextualitás: létmód és/vagy funkció. Hagyomány és kontextus. Universitas, Budapest. 495-538.

LENGYEL ANDRÁs 2000. Játék és valóság közt: Kosztolányi-tanulmányok. Tiszatáj könyvek. Tiszatáj, Szeged.

PÁJI GRÉTA 2016a. A Sárszeg helynevek kontextuális hasonlóságai és különbségei a Kosztolányi-életmü szövegeiben. In: KOCSIS ZSUZSANNA - NÉMETH LUCA ANNA - TAKÁCS 
EDIT szerk., Találkozások Félúton. Az Eötvös Loránd Tudományegyetem Nyelvtudományi Doktori Iskolájának 10. Félúton konferenciáján elhangzott elöadások tanulmánykötete. ELTE BTK Magyar Nyelvtudományi és Finnugor Intézet, Budapest. 80-91.

PÁJI GRÉTA 2016b. Írói névadási tendenciák és stratégiák Kosztolányi Dezső novellái alapján. Névtani Értesitö 38: 85-99.

PÁJI GRÉTA megj. e. Az írói névadásbeli változtatások lehetséges okairól és az olvasói asszociációkról Kosztolányi Dezső szépprózai müvei kapcsán. In: KoCSIS ZSUZSANNA - KRIZSAi FruZSINA - NÉMETH LuCA ANNA szerk., Félúton 11. Az ELTE BTK Nyelvtudományi Doktori Iskolájának konferenciája 2015. október 8-9. Megjelenés előtt.

PARÁdi ANDREA 2014. Kézirat. In: Kosztolányi Dezső, Aranysárkány. Szerk. Bengi LÁSZló - PARÁdi ANDREA. Kritikai kiadás. Kalligram, Pozsony.

SLÍZ MARIANN 2007. Név és névtelenség Italo Calvino „A nemlétező lovag” címü müvében. Névtani Értesítö 29: 161-165.

SLÍz MARIANN 2013. Rúth Rhonda és Phil O’Dendron. A névadás szerepe a paródiában. In: VARGHA KATALIN - T. LitKOVKINA ANNA - BARTA ZSUZSANNA szerk., Sokszinü humor. A III. Magyar interdiszciplináris Humorkonferencia elöadásai. Segédkönyvek a nyelvészet tanulmányozásához 151. Tinta Könyvkiadó, Budapest. 81-89.

SLÍZ MARIANN 2014. Az irodalmi nevek mint szignálok üzeneteinek kiválasztása. In: BAUKO JÁNOS - BENYOVSZKY KRISZTián szerk., A nevek szemiotikája. Nyitrai Konstantin Filozófus Egyetem Közép-európai Tanulmányok Kara - Magyar Szemiotikai Társaság, Nyitra-Budapest. 217-226.

SzEGEDY-MASZÁK MiHÁly 1980. Az Esti Kornél jelentésrétegei. In: SzEGEDY-MASZÁK MiHÁly, „A regény, amint írja önmagát”: Elbeszélő müvek vizsgálata. Müelemzések kiskönyvtára 11. Tankönyvkiadó, Budapest. 103-151.

Szegedy-MaszÁK Mihály 2010a. Kosztolányi Dezső. Kalligram, Pozsony. 318-355.

SZEGEDY-MASZÁK MiHÁLY 2010b. „Képről készitek képet”. Alföld 11: 104-108.

SzIKSZAINÉ NAGY IRMA 1999. Leíró magyar szövegtan. Osiris Kiadó, Budapest.

TÁTRAi SzILÁRD 1997. Az elbeszélés határai: Kosztolányi Dezső: Esti Kornél. Magyar Nyelvör 121: 325-338.

TÁTRAI SzILÁRD 2000. Az 'ÉN'az elbeszélésben. A perszonális narráció szövegtani megközelítése. Argumentum, Budapest.

TÁTRAI SzILÁRD 2017. Esti Kornél és a beégés. Megjegyzések a müfajiság pragmatikai vonatkozásaihoz. Magyar Nyelv 113: 290-301. https://doi.org/10.18349/[-] MagyarNyelv.2017.3.290

Tolcsvai NAGY GÁBOR 2008. A tulajdonnév jelentése. In: BÖlCSKEI ANDREA - N. CSÁszi ILDIKÓ szerk., Név és valóság. A VI. Magyar Névtudományi Konferencia előadásai (Balatonszárszó, 2007. június 22-24.). A Károli Gáspár Református Egyetem Magyar Nyelvtudományi Tanszékének Kiadványai 1. Károli Gáspár Református Egyetem Magyar Nyelvtudományi Tanszék, Budapest. 30-41.

TÓTH-CZIFRA Júlia 2010. Rész és egész (Kosztolányi Dezső Esti Kornél-történeteinek geneziséről). Tiszatáj 64/5: 64-76.

TóTH-CZIFRA JúLIA 2011a. Az Esti Kornél (1933) keletkezéstörténete. In: Kosztolányi 2011: 496-549.

TÓTH-CZIFRA JÚLIA 2011b. Szövegkritika. In: Kosztolányi 2011: 454-496. 
Vathy Zsuzsa 2006. Bolgár kalauzom. Tiszatáj 60/4: 47-51.

VÁCZINÉ TAKÁCS EDIT 2018. Az írói névadás sajátosságai Karinthy Frigyes müvei alapján. Magyar Névtani Értekezések 6., Az ELTE BTK Magyar Nyelvtudományi és Finnugor Intézet Magyar Nyelvtörténeti, Szociolingvisztikai, Dialektológiai Tanszékének sorozata. Magyar Nyelvtudományi Társaság - ELTE BTK Magyar Nyelvtörténeti, Szociolingvisztikai, Dialektológiai Tanszéke, Budapest. 67.

VERES ANDRÁS 2011. Az Esti Kornél befogadástörténete. In: Kosztolányi 2011: 573-839.

\section{Names as intertextual linguistic items in the Esti Kornél short stories}

The paper discusses intertextual possibilities of reading based on the title hero's name in Esti Kornél texts written by Dezső Kosztolányi, an outstanding writer of modern Hungarian literature in general and of the first generation of the journal Nyugat in particular. This relationship between the text and the receiver can be described as a set of reflected or unwitting associations. Within the oeuvre of Kosztolányi, these texts are of debatable genres and loosely related to one another, mainly in terms of proper names and some recurrent themes rather than linearity and explicitness, thereby emphasising the fictitiousness of the stories. The name Esti Kornél serves as a kind of associative link across these texts, as well as in contemporary texts of fiction that contain it; it has an intertextual role by evoking earlier contexts in which the name occurred and the properties that were associated with it in earlier texts.

Keywords: Esti Kornél, intertextuality, associations, contexts, semantic structure.

PÁJI GRÉTA

ELTE Eötvös Loránd Tudományegyetem 